\title{
Jurnal Kedokteran
}

p-ISSN : 2686-1437

e-ISSN : 2686-0201

http://ejournal.ukrida.ac.id/ojs/index.php/Meditek/index

\section{Efektivitas Extraoral Suction dalam Praktik Kedokteran Gigi di Masa Pandemi COVID-19}

\author{
Carolina Stevanie \\ Universitas Prof. Dr. Moestopo (Beragama), Jakarta, Indonesia \\ Alamat Korespondensi: cstevanie95@gmail.com
}

\begin{abstract}
Abstrak
Aerosol berpotensi menjadi jalur transmisi COVID-19. Aerosol merupakan partikel kecil berukuran kurang dari 0,5-10 $\mu$ yang terbentuk selama berbicara, batuk, dan bersin. Disamping itu dapat pula terbentuk akibat penggunaan instrumentasi pada kegiatan praktik Kedokteran Gigi. Virus COVID-19 yang terbawa dalam aerosol dapat bertahan selama 3 jam, dengan masa hidup 1,1 -1,2 jam. Melalui media transport aerosol, virus dapat berpindah hingga hampir $200.000 \mathrm{~km}$ horizontal. Penggunaan kombinasi intraoral suction dan extraoral suction dinilai efektif dalam menurunkan resiko transmisi COVID-19 melalui aerosol dalam praktik Kedokteran Gigi. Extraoral suction bekerja melalui mekanisme penyaringan, desinfeksi sinar UV, plasma ion, serta HEPA, sehingga udara yang dikeluarkan dari mesin extraoral suction merupakan udara yang aman dan bebas dari virus. Tujuan penulisan tinjauan pustaka ini adalah memberikan paparan mengenai efektivitas penggunaan extraoral suction dalam mengurangi produksi dan peredaran aerosol selama prosedur perawatan Kedokteran Gigi.
\end{abstract}

Kata Kunci: aerosol, COVID-19, extraoral suction, Kedokteran Gigi

\section{Extraoral Suction Effectivity in Dentistry During COVID-19 Pandemic}

\begin{abstract}
COVID-19 virus can be potentially transmitted by aerosol. Aerosol is defined as small particles of less than 0.5-10 micron which can be produced during talking, coughing and sneezing. In addition, aerosol can be produced by instrumentation during dental procedure. The purpose of this literature review is to explain the effectiveness of extra-oral suction usage for reducing aerosol production and circulation during dental procedure. COVID-19 virus brought by aerosol tend to stay airborne for 3 hours with 1.1-1.2 hours of lifespan. By using aerosol as transport media, virus can travel almost $200.000 \mathrm{~km}$ horizontally. A combination of intraand extra-oral suction in dental clinics or hospitals are believed to be effective for reducing the risk of COVID19 transmission by aerosol during dental practice. The study recommends further research by microbiology specialists and dental technology experts to confirm this.
\end{abstract}

Keywords: Aerosol, COVID-19, dentistry, extra-oral suction

\section{Pendahuluan}

COVID-19 diketahui pertama kali menyebar di wilayah Wuhan, China melalui spesies kelelawar China (Rhinolophus sinicus) ke manusia. Penyebarannya yang terjadi dengan cepat menyebabkan COVID-19 ditetapkan sebagai pandemi oleh WHO (World Health Organization) pada 12 Maret 2020. Virus SARS-CoV-2 (virus COVID-19) merupakan virus single-stranded RNA (asam ribonukleat), dengan tampilan seperti mahkota jika dilihat pada mikroskop elektron karena adanya duri-duri glikoprotein pada lapisan luarnya. ${ }^{1,2}$ Virus ini berukuran diameter $65-125 \mathrm{~nm}$

\section{How to Cite}

Stevanie C. Efektivitas Extraoral Suction dalam Praktik Kedokteran Gigi di Masa Pandemi COVID-19. JKdoktMeditek.2020;26(3):159-163. 
dan panjang 26-32kbs (kilobase). Penyebaran COVID-19 terjadi melalui droplet, kontak fisik, fecal-oral, dan aerosol.,

Individu yang terinfeksi COVID-19 umumnya menunjukkan gejala seperti pneumonia yaitu demam, batuk kering, nafas pendek, cepat lelah, kehilangan indera penciuman, sakit kepala, dengan gambaran khas CT-Scan paru-paru berupa infiltrasi bilateral (ground glass imaging). ${ }^{1,4-6}$

Dalam praktik Kedokteran Gigi, transmisi COVID-19 dapat terjadi melalui aerosol dan splatter dari rongga mulut pasien. Aerosol merupakan singkatan dari aero-solution dan didefinisikan sebagai partikel airborne yang berukuran 0,5-10 $\mu^{11}$ Aerosol dapat dihasilkan selama intrumentasi saluran pernafasan atas (rongga mulut dan hidung), cairan irigasi, maupun bahan lain yang bercampur dengan darah, saliva, serta bakteri yang dapat menghasilkan partikel aerosol dan berpotensi menularkan penyakit. ${ }^{7-10}$

Partikel dengan ukuran dibawah $50 \mu$ cukup untuk bertahan di udara selama beberapa waktu sebelum akhirnya menempel pada permukaan sekitar atau terhirup dan masuk ke saluran pernafasan. ${ }^{11} \quad$ Splatter/droplet didefinisikan sebagai partikel dengan diameter lebih besar dari $50 \mu$. Droplet bergerak secara balistik, artinya partikel dikeluarkan dengan tekanan dari sumbernya dan melesat seperti peluru hingga berkontak dengan suatu permukaan atau jatuh ke lantai. Aerosol dan droplet dapat menularkan penyakit seperti tuberkulosis (TBC), virus, pneumonitis, influenza, termasuk virus COVID19. Udara menjadi sarana penularan dengan jarak yang lebih jauh. Melalui udara, spora jamur dapat menyebar sejauh $150 \mathrm{~m}$, sedangkan virus dapat berpindah hampir $200.000 \mathrm{~km}$ secara horizontal. ${ }^{7-}$ 8,10-12

Profesi dokter gigi menempati urutan pertama pekerjaan paling beresiko terpapar COVID-19, dikarenakan area kerja dokter gigi berada disekitar mulut dan wajah pasien, berkontak dengan saliva serta adanya kemungkinan terjadi produksi aerosol selama perawatan (Tabel 1). ${ }^{13,14,16}$

\section{Tabel 1. Daftar Pekerjaan Beresiko Terpapar COVID-19 ${ }^{13}$}

\begin{tabular}{cc}
\hline Pekerjaan & $\begin{array}{c}\text { Derajat Risiko } \\
(\%)\end{array}$ \\
\hline Ahli Kesehatan Gigi & 99,7 \\
Teknisi Terapi Respirasi & 95,0 \\
Asisten Kedokteran Gigi & 92,5 \\
Dokter Gigi Umum & 92,1 \\
Mantri (Asisten pasien) & 90,2 \\
Dokter umum dan Dokter Keluarga & 90,1 \\
Perawat Terdaftar & 86,1 \\
Terapis Respirasi & 84,2 \\
Teknisi Radiologi & 84,1 \\
Perawat Praktik dan Kejuruan Berlisensi & 82,1 \\
\hline
\end{tabular}

Hal ini menjadi perhatian bagi tenaga kesehatan, khususnya dokter gigi dalam mempersiapkan protokol saat melakukan perawatan gigi di Klinik Gigi maupun Rumah Sakit. Dalam praktik Kedokteran Gigi upaya pencegahan penularan dilakukan dengan penggunaan alat pelindung diri (APD) berupa masker bedah, googles, face shield, sarung tangan, serta gown. Selain itu, dalam praktik Kedokteran Gigi umumnya digunakan intraoral suction untuk mengevakuasi cairan saliva, darah, dan air dari dalam rongga mulut pasien selama proses perawatan gigi. ${ }^{5,17,18}$

Seperti halnya intraoral suction (IOS), Extraoral suction (EOS) merupakan alat yang digunakan untuk menghisap droplet dan aerosol yang terbentuk selama perawatan gigi. Bedanya extraoral suction bekerja di luar mulut pasien dengan daya hisap yang lebih besar hingga 3000 L/Menit, sedangkan daya hisap intraoral suction sebesar 180 L/menit. Extraoral suction memproduksi suara yang lebih keras dibanding air purifier yaitu sebesar 50-75 desibel dan terdiri dari sistem penyaringan HEPA (High Efficiency Particulate Air) $\mathrm{H} 13$ yang teruji klinis, ion plasma, dan desinfektan sinar UV (ultraviolet) yang mampu memusnahkan virus dan bakteri. ${ }^{12,17,18,20,21,25}$

Penggunaan extraoral suction memberikan rasa aman bagi pasien, dokter gigi serta asisten dokter gigi, namun belum diketahui seberapa efektif alat ini dalam menekan penyebaran aerosol. Oleh karena itu tinjauan pustaka ini akan menjelaskan efektivitas extraoral suction dalam menekan penyebaran aerosol selama praktik Kedokteran Gigi di masa pandemi COVID-19.

\section{Transmisi COVID-19 Melalui Aerosol dalam Praktik Kedokteran Gigi}

Transmisi COVID-19 dalam praktik kedokteran gigi mencakup 4 cara, yaitu: ${ }^{12,22}$ 
1. Paparan langsung terhadar sekresi saluran pernafasan meliputi saliva, darah, droplet, atau material lain dari pasien.

2. Kontak tidak langsung dengan permukaan dan instrumen terkontaminasi.

3. Menghirup virus yang beredar secara airborne.

4. Kontak mukosa (hidung, rongga mulut, konjungtiva) dengan droplet atau aerosol mengandung virus, saat berbicara atau batuk tanpa penggunaan masker medis dan kaca mata pelindung.

Saliva mengandung virus COVID-19 dalam jumlah tinggi, hingga $1,2 \times 10^{8}$ infective copies $/ \mathrm{mL}$ dan lebih banyak pada area nasofaring dibanding orofaring. Droplet saliva dapat berpindah dalam jarak yang jauh atau pendek ditentukan dari ukurannya. Umumnya infeksi saluran pernafasan ditularkan melalui droplet berukuran besar, dalam jarak yang dekat atau karena kontak dengan permukaan terkontaminasi. ${ }^{7,9,11,21,27}$

Droplet berukuran besar (diameter di atas 50 $\mu$ ) bertahan dalam waktu singkat di udara, sehingga resiko penularan patogen terbatas pada individu yang berdekatan dengan individu terinfeksi. Droplet berukuran kecil cenderung menguap menjadi nukleus droplet (diameter kurang dari 10 $\mu)$ pada lingkungan tertentu, dan berpotensi menularkan dalam jarak yang lebih jauh sebagai aerosol. ${ }^{9,11,21}$

Penggunaan handpiece high-speed disertai air, ultrasonic scaler, dan syringe udara/air menyebabkan terbentuknya droplet dan aerosol yang bercampur dengan saliva dan darah dari rongga mulut pasien (Tabel 2). 5,11,12,22,24

Tabel 2 . Peralatan dan Prosedur Kedokteran gigi yang Diketahui Menghasilkan Kontaminasi Airborne ${ }^{12}$

\begin{tabular}{cl}
\hline Alat dan prosedur kedokteran gigi & \multicolumn{1}{c}{ Tingkat aerosol yang dihasilkan } \\
\hline \multirow{2}{*}{ Scaler Ultrasonik dan sonik } & Dipertimbangkan sebagai sumber terbesar kontaminasi aerosol. \\
& Menggunakan High-Volume Evacuator (HVE) dapat mengurangi \\
kontaminasi airborne hingga lebih dari 95\%. & Penghitungan bakteri menunjukkan kontaminasi airborne setara \\
Air polishing & dengan penggunaan ultrasonic scaler. Alat hisap yang tersedia \\
& dapat mengurangi kontaminasi hingga lebih dari 5\%. \\
Air- water syringe & $\begin{array}{l}\text { Penghitungan bakteri menunjukkan kontaminasi airborne setara } \\
\text { dengan penggunaan ultrasonic scaler. High-Volume Evacuator } \\
\text { dapat mengurangi bakteri airborne higga 99\%. }\end{array}$
\end{tabular}

Preparasi gigi dengan handpiece air turbine $\quad$ Kontaminasi airborne minimal bila menggunakan rubber dam. berlebih oleh partikel abrasif.

Transmisi COVID-19 melalui aerosol membutuhkan perhatian khusus, karena meskipun berbagai langkah pencegahan dilakukan hampir mustahil dapat menghilangkan produksi aerosol dan droplet saat perawatan gigi. ${ }^{17}$ Penelitian menunjukan bahwa Virus SARS-CoV-2 (virus COVID-19) dapat bertahan sebagai aerosol selama 3 jam dan memiliki masa hidup rata rata 1,1 hingga 1,2 jam serta dapat bertahan pada permukaan besi, kaca, ataupun plastik dalam beberapa hari. ${ }^{11,22,27,24}$

Virus COVID-19 bertahan dalam suatu ruangan dengan suhu ruang $\left(25^{\circ} \mathrm{C}\right)$ selama 2 jam hingga 9 hari. Tingkat kelembaban $50 \%$ suatu ruangan menyebabkan aktifitas virus COVID-19 lebih tinggi dibanding 30\%. ${ }^{17}$ Oleh karena itu sangat penting menjaga lingkungan praktik kedokteran gigi tetap kering dan bersih untuk menekan masa hidup virus COVID-19 dan mencegah penyebaran lebih lanjut. . $2,28^{2}$

\section{Efektivitas Extraoral Suction dalam Mengurangi Aerosol dalam Praktik Kedokteran Gigi}

Berbagai klinik dokter gigi dan rumah sakit memanfaatkan extraoral suction untuk mengurangi penyebaran aerosol dan droplet selama perawatan gigi.

1. Extraoral suction memiliki 2 bagian utama.

2. Suction unit: Lengan suction harus cukup panjang untuk dapat mencapai area kerja dan asisten. Four-handed dentistry membutuhkan lengan suction sedikitnya $1,5 \mathrm{~m}$ atau lebih panjang. Dengan daya listrik diatas 1000 watt memberikan daya hisap aerosol yang lebih besar. ${ }^{25}$

3. Sterilizer unit (seperti air purifier): Untuk mendesinfeksi aerosol yang terhisap, extraoral suction memerlukan 4 mekanisme utama, yaitu: penyaring utama, sinar UV, ion plasma, dan penyaring HEPA. ${ }^{19,20,25}$ 
Penyaring utama membersihkan seluruh debu dan partikel debris yang tercampur dengan udara dan air pada aerosol. Udara yang sudah disaring disterilisasi dengan sinar UV yang dapat membunuh mikroba dan virus. Ion plasma 9 (+ve dan - ve) memiliki peran penting menghilangkan dan membunuh mikroba dan virus. Mikroba dan virus dapat menempel pada permukaan dan bertambah besar ukurannya. Penyaring HEPA pada extraoral suction mampu menyaring 95\% partikel berukuran 0,3 mikron atau lebih besar. ${ }^{19,20,23,25}$

Umumnya penyaring HEPA saat ini terdiri dari tautan fiber glass yang diputar dan dipelintir ke berbagai arah untuk menciptakan bentuk labirin. Ketika suatu partikel memasuki area ini, akan dibersihkan melalui mekanisme berikut: ${ }^{24}$

1. Dampak langsung: kontaminan besar, seperti debu, jamur, serbuk sari, akan bergerak ke suatu jalur yang kemudian tertahan oleh fiber, dan menempel dalam fiber tersebut.

2. Proses pengayakan: aliran udara akan membawa partikel ke antara 2 fiber. Partikel yang lebih besar dari jarak kedua fiber tersebut akan tertahan.

3. Proses penangkapan partikel: Aliran udara dapat mengubah rute pergerakan partikel, namun karena adanya kelembaban, partikel tetap bergerak sesuai arahnya dan menempel pada fiber.

4. Proses difusi: partikel kecil hingga sangat kecil bergerak lebih tidak menentu dibanding partikel besar, sehingga cenderung tertahan dan menempel pada fiber.

Setelah melewati seluruh proses tersebut, hasil akhir mesin extraoral suction ini adalah berupa udara yang bersih dan aman. ${ }^{24,25}$

Kombinasi penggunaan extraoral dan intraoral suction memberikan hasil maksimum dalam mengurangi aerosol selama perawatan. Dalam menggunakan alat suction, dokter gigi dapat menempatkan intraoral suction 2-5 inci (1 inci $=2,54 \mathrm{~cm}$ ) dari instrumen yang sedang digunakan didalam rongga mulut, dan extraoral suction diletakkan 6-12 inci dari pasien. ${ }^{17,23}$

Berdasarkan penelitian yang dilakukan oleh Motegi et al. (2010) penggunaan intraoral suction tanpa extraoral suction menunjukkan bahwa $40 \%$ $60 \%$ partikel aerosol $(0,5 \mu)$ terdistribusi ke sekitar wajah pasien, sedangkan penggunaan kombinasi intraoral suction dan extraoral suction menunjukkan tidak terdapat partikel aerosol yang terdistribusi ke wajah pasien karena seluruhnya terhisap oleh extraoral suction. Hal ini didukung oleh penelitian yang dilakukan oleh Teanpaisan (2001) yang membandingkan pengaruh penggunaan extraoral suction terhadap jumlah koloni bakteri yang tersebar melalui aerosol saat praktik Kedokteran gigi menggunakan media agar. Penelitian ini membuktikan adanya penurunan jumlah koloni bakteri signifikan pada penggunaan extraoral suction. ${ }^{17,18,20}$

\section{Penutup}

Produksi aerosol selama perawatan gigi perlu menjadi perhatian khusus, karena dapat menjadi jalur transmisi virus COVID-19. Penggunaan kombinasi intraoral suction dan extraoral suction sangat direkomendasikan karena mampu mengurangi beredarnya aerosol saat perawatan gigi, sehingga dapat menekan resiko penularan COVID-19 diantara pasien, dokter gigi, dan perawat selama bekerja serta memberi rasa aman pada pasien yang memerlukan perawatan gigi.

\section{Saran}

Diperlukan penelitian serta penjelasan lebih lanjut mengenai efektivitas extraoral suction dalam menekan penyebaran aerosol sebagai upaya pencegahan penularan COVID-19 oleh ahli mikrobiologi dan ahli teknologi kedokteran gigi.

\section{Daftar Pustaka}

1. Gennaro F, Pizzol D, Marotta C, et al. Coronavirus diseases (COVID-19) current status and future perspectives: A narrative review. International Journal of Environmental Research and Public Health. 2020;17(8).

2. Ahmed M, Jouhar R, Ahmed N, et al. Fear and practice modifications among dentists to combat novel coronavirus disease (COVID19) outbreak. International Journal of Environmental Research and Public Health. 2020;17(8).

3. Shereen M, Khan S, Kazmi A, et al. COVID19 infection: Origin, transmission, and characteristics of human coronaviruses. Journal of Advanced Research. 2020;24:918.

4. Baghizadeh M. What dentists need to know about COVID-19. Oral Oncology. 2020;105:104741.

5. Ather A, Patel B, Ruparel $\mathrm{N}$, et al. Coronavirus disease 19 (COVID-19): Implications for clinical dental care. Journal of Endodontics. 2020;46(5):584-95. 
6. Lucaciu O, Tarczali D, Petrescu N. Oral healthcare during the COVID-19 pandemic. Journal of Dental Sciences. 2020;40:10-3.

7. Kerawala C, Riva F. Aerosol-generating procedures in head and neck surgery - can we improve practice after COVID-19? British Journal of Oral and Maxillofacial Surgery. 2020:58(6):704-7.

8. Aldahlawi A, Afifi K. COVID-19 in dental practice: Transmission risk, infection control challenge, and clinical implications. The Open Dentistry Journal. 2020;14(1):348-54.

9. Ramesh M, Arun R, Priyadharshini I. Review article aerosol suction device: Mandatory armamentarium in dentistry post lock down. Journal of Advanced Medical and Dental Sciences Research. 2018;6(7):129-33.

10. Eliades T, Koletsi D. Minimizing the aerosolgenerating procedures in orthodontics in the era of a pandemic: Current evidence on the reduction of hazardous effects for the treatment team and patients. American Journal of Orthodontics and Dentofacial Orthopedics. 2020;158(3):330-42.

11. Heikkinen M, Hjelmroos-Koski M, Haggblom M, et al. Aerosols handbook: Measurement, dosimetry, and health effects. 2005;1:290-329.

12. Harrel S, Molinari J. Aerosol and splatter in dentistry. Journal of American Dental Association. 2004;135:429-37.

13. $\mathrm{Lu} \mathrm{M}$. These are jobs most at risk from COVID-19 transmission. [internet]. 2020. [cited 2020 Sept 26]. Available from: https://www.weforum.org

14. Gamio L. The workers who face the greatest coronavirus risk. [internet]. 2020. [cited 2020 Sept 26]. Available from: https://www.nytimes.com

15. Meng L, Hua F, Bian Z. Coronavirus disease 2019 (COVID-19): Emerging and future challenges for dental and oral medicine. Journal of Dental Research. 2020;99(5):4817.

16. Which occupations have the highest potential exposure to the coronavirus COVID-19. [internet]. 2020. [cited 2020 Sept 28]. Available from: https://www.ons.gov.uk

17. Motegi N, Ikegami Y, Chiba M, Asano Y. How much extra-oral suction (EOS) can prevent dental aerosols. Dental Outlook. 2010;115(6):1-18.

18. Oral Health Division. Ministry of Health Malaysia. Extra-oral vacuum aspirator/ suction, 3. 1-3. [Internet]. 2020. [cited 2020 Nov 3]. Available from: http://ohd.moh.gov.my
19. Samaranayake L, Perera F, Buranawat B. The efficacy of bio-aerosol reducing procedures used in dentistry: A systematic review. Preprints, 2020; 1-30.

20. Teanpaisan R, Taeporamaysamai M, Rattanachone $\mathrm{P}$, et al. The usefulness of the modified extra-oral vacuum aspirator (EOVA) from household vacuum cleaner in reducing bacteria in dental aerosols. International Dental Journal. 2001;51(6):413-6.

21. American Association of Oral and Maxillofacial Surgeons. Intraoral vs extraoral suction devices Vol. 115(6). [Internet]. 2020. [cited 2020 Sept 28]. Available from: https://www.aaoms.org

22. Fallahi R, Keyhan O, Zandian D, et al. Being a front-line dentist during the Covid-19 pandemic: a literature review. Maxillofacial Plastic and Reconstructive Surgery. 2020;42(1).

23. Versaci Mary. COVID-19 pandemic may lead dentist to consider buying air filters, uvc lights, suction devices. [internet]. 2020. [cited 2020 Nov 3]. Available from: https://www.ada.org

24. The pH Dental. Essential tips to know before you buy extraoral dental suction system. [internet]. 2020. [cited 2020 Nov 3]. Available from: https://phdentalinc.com

25. Unicorn. Extraoral suction: must require equipment for safety from aerosols transmitted viral and microbial infections. [Internet]. 2020. [cited 2020 Sept 29]. Available from: http://www.unicorndenmart.com

26. Xu R, Cui B, Duan X, et al. Saliva: potential diagnostic value and transmission of 2019$\mathrm{nCoV}$. International Journal of Oral Science. 2020;12(1).

27. Miller L, Nazaroff W, Jimenez L, et al. Transmission of SARS-CoV-2 by inhalation of respiratory aerosol in the Skagit Valley Chorale superspreading event. 2020;1-12.

28. Morawska L, Tang W, Bahnfleth W, et al. How can airborne transmission of COVID-19 indoors be minimized? Environment International. 2020;142.

29. Desarda H, Gurav A, Dharmadhikari C, et al. Efficacy of high-volume evacuator in aerosol reduction: Truth or myth? a clinical and microbiological study. Journal of Dental Research, Dental Clinics, Dental Prospects. 2014;8(3):176-9. 